
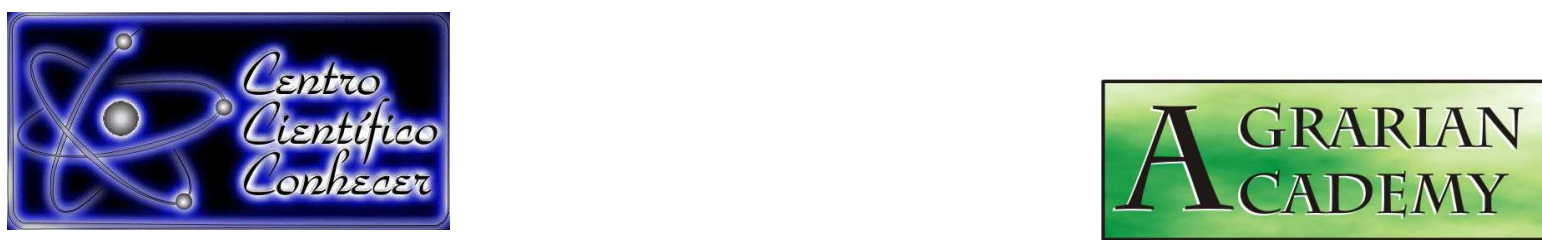

\title{
PRODUTIVIDADE E RETORNO ECONÔMICO DA CULTURA DA SOJA COM TECNOLOGIA INTACTA ${ }^{\circledR}$
}

\author{
Mateus Goffi ${ }^{1}, \underline{\text { Siumar Pedro Tironi }}^{2}$, André Luiz Radünz ${ }^{3}$, Marco Aurélio Tramontin ${ }^{4}$ \\ ${ }^{1}$ Engenheiro Agrônomo, empresa AgriCenter, Seberi, RS, Brasil. E-mail: \\ mateus goffi@hotmail.com \\ ${ }^{2}$ Professor Doutor, Universidade Federal da Fronteira Sul (UFFS), Chapecó, SC, \\ Brasil. E-mail: siumar.tironi@uffs.edu.br \\ ${ }^{3}$ Professor Doutor, Universidade Federal da Fronteira Sul (UFFS), Chapecó, SC, \\ Brasil. E-mail: marco.silva@uffs.edu.br \\ ${ }^{4}$ Professor Doutor, Universidade Federal da Fronteira Sul (UFFS), Chapecó, SC, \\ Brasil. E-mail: andre.radunz@uffs.edu.br
}

Recebido em: 15/04/2017 - Aprovado em: 22/07/2017 - Publicado em: 31/07/2017 DOI: 10.18677/Agrarian_Academy_2017a37

\begin{abstract}
O alto potencial produtivo da cultura da soja pode ser comprometido pelo ataque de insetos-praga, especialmente da ordem Lepidoptera. Para o manejo dessas pragas surgiu a tecnologia da soja Intacta ${ }^{\circledR}$, obtida pelo processo de transgenia em que a planta sintetiza uma proteína que é tóxica para as larvas de certo grupo de lepidópteros. Assim, foi conduzido um experimento a campo com o objetivo de avaliar a produtividade, resistência às lagartas, o custo de produção e o retorno econômico da soja com e sem a tecnologia Intacta ${ }^{\circledR}$. O delineamento experimental utilizado foi de parcelas subdivididas, em esquema fatorial $(2 \times 4)$ com quatro repetições. Nas parcelas foram alocadas as cultivares de soja NS 5959 IPRO ${ }^{\oplus} \mathrm{com}$ a tecnologia Intacta ${ }^{\circledR}$ e NA 5909 RR $^{\circledR}$ sem a tecnologia Intacta ${ }^{\Theta}$; nas sub parcelas foram alocados os inseticidas: cipermetrina $\left(50 \mathrm{~g} \mathrm{ha}^{-1}\right)$, teflubenzurom $\left(15 \mathrm{~g} \mathrm{ha}^{-1}\right)$, cipermetrina (50 $\left.\mathrm{g} \mathrm{ha}^{-1}\right)+$ teflubenzurom $\left(15 \mathrm{~g} \mathrm{ha}^{-1}\right)$ em associação e uma testemunha sem aplicação. Observou-se que a soja com a tecnologia Intacta ${ }^{\circledR}$ teve um melhor desenvolvimento em comparação à soja sem a tecnologia, com menor ataque de lagartas. A cultivar Intacta ${ }^{\circledR} \mathrm{NS} 5959 \mathrm{IPRO}{ }^{\circledR}$ apresentou maior peso de mil grãos. A produtividade foi superior na cultivar com a tecnologia Intacta ${ }^{\circledR}$; para obtenção de maior produtividade da cultivar sem a tecnologia Intacta ${ }^{\circledR}$ é necessária a aplicação continua de inseticidas. Apesar do custo de produção da soja com a tecnologia Intacta ${ }^{\circledR}$ ser mais elevado, essa cultivar promove maior retorno econômico.
\end{abstract}

RESUMO

PALAVRAS-CHAVE: Anticarsia gemmatalis. Custo de Produção. Transgenia. 


\title{
PRODUCTIVITY AND ECONOMIC RETURN OF SOYBEANS CULTIVAR WITH INTACTA $^{\circledR}$ TECHNOLOGY
}

\begin{abstract}
The high yield potential of the soybean crop can be compromised by the attack of insect, especially Lepidoptera Order. For the management of these pests there were the Intacta ${ }^{\circledR}$ soybean technology, obtained by the transgenic process in which plant synthesizes a protein that is toxic to the larvae of certain Lepidoptera group. In this sense, an experiment was carried out with the objective of evaluating the productivity, resistance to caterpillars, and the cost of production of soybean cultivar NS 5959 IPRO $^{\circledR}$ with and without Intacta ${ }^{\circledR}$ technology. The experimental design was a split plot factorial $(2 \times 4)$ with four replications. In the plots were allocated the soybean cultivars NS 5959 IPRO $^{\circledR}$ with Intacta ${ }^{\circledR}$ technology and NA 5909 RR $^{\circledR}$ without this technology; sub parts has been allocated the insecticides: cypermethrin (200 ml ha-1), teflubenzuron $\left(100 \mathrm{ml} \mathrm{h}^{-1}\right)$, cypermethrin $\left(200 \mathrm{~g} \mathrm{~h}^{-1}\right)+$ teflubenzuron $\left(100 \mathrm{ml} \mathrm{h}^{-1}\right)$ in association and a control without application. It was observed that with soy Intacta ${ }^{\circledR}$ technology had a better development compared to soybean without technology, with lower caterpillars attack. The grains of the Intacta ${ }^{\circledR}$ cultivate NS 5959 IPRO $^{\circledR}$ showed greater weight than the NA $5909 \mathrm{RR}^{\circledR}$. The achieved productivity was higher in cultivar with Intacta $^{\circledR}$ technology, as to obtain higher productivity of farming without Intacta ${ }^{\circledR}$ technology spraying insecticides is required. Despite the soybean production cost with technology Intacta ${ }^{\circledR}$ be higher the gain in productivity is greater, this cultivar promoters greater economic returns.
\end{abstract}

KEYWORDS: Anticarsia gemmatalis. Production Cost. Transgenia.

\section{INTRODUÇÃO}

A soja (Glycine max) destaca-se como uma das principais culturas agrícolas no cenário nacional e mundial. Isso devido ao seu elevado potencial produtivo e ao alto valor nutritivo, que possibilita diversas aplicações na alimentação humana e animal (MAUAD et al., 2010; CUNHA et al., 2015). O Brasil se destaca como um dos maiores produtores e exportadores mundiais de soja, juntamente com os Estados Unidos da América, com aproximadamente 33,9 milhões de hectares cultivados na última safra. Apenas na região sul é cultivado, aproximadamente, 11,5 milhões de hectares (CONAB, 2017).

O potencial de produtividade da cultura da soja, em nível nacional, bem como em todas as regiões produtoras, nas últimas safras, mostra-se elevado, tornando o Brasil um produtor com capacidade competitiva de produção dessa cultura. Fica evidente que as novas tecnologias vêm possibilitando o cultivo em novas áreas e, consequentemente, gerando o aumento da área cultivada. $O$ desenvolvimento de novas tecnologias é um dos grandes responsáveis pelo aumento da produção de soja no Brasil (FREITAS \& MENDONÇA, 2016).

A soja destaca-se, no Brasil, como o principal produto agrícola, com potencial para crescer ainda mais em produção, em função do aumento da produtividade e área cultivada. Com o desempenho apresentado nos últimos anos, vem sendo um dos mais importantes produtos da economia brasileira, atuando na geração de divisas, e através do enorme complexo, na geração de empregos (FREITAS \& MENDONÇA, 2016).

Para aumentar a produtividade da cultura da soja devem-se reduzir as perdas causadas pelos fatores limitantes. Dentre os principais fatores limitantes da AGRARIAN ACADEMY, Centro Científico Conhecer - Goiânia, v.4, n.7; p.381 2017 
produtividade da cultura da soja destacam-se o ataque de insetos-praga, em especial da lagarta-da-soja (Anticarsia gemmatalis - Lepidoptera: Noctuidae), considerado o principal inseto desfolhador da cultura, podendo ocasionar grandes impacto na produtividade da mesma (LOURENÇÃO et al., 2010). Essa praga apresenta elevada ocorrência, com necessidade de controle frequente, considerando que o método mais utilizado é o químico ou com uso de plantas transgênicas resistentes (MORALES \& SILVA, 2006; CRIALESI-LEGORI et al., 2014).

As lagartas atacam as folhas da soja, raspando-as quando as larvas encontram-se nas primeiras fases de desenvolvimento (quando são pequenas), ocasionando manchas claras, à medida que as mesmas se desenvolvem ficam mais vorazes e destroem completamente as folhas atacadas, podendo danificar as hastes, floração e até as vagens (HOFFMANN-CAMPO et al., 2000).

Em alguns casos, com a elevada incidência dessa praga, há a necessidade de várias aplicações de inseticidas durante todo o ciclo da cultura, chegando a uma média de quatro a seis aplicações durante o ciclo (MORALES \& SILVA, 2006) ou até mais em alguns casos extremos. Esse método de controle gera um incremento substancial de uso de agrotóxicos nas lavouras, que pode elevar o impacto ambiental e os custos de produção para os agricultores.

Vários grupos de inseticidas são recomendados para o controle das lagartas na cultura da soja, tais como os organofosforados que, apesar dos benefícios que esse grupo de inseticidas proporciona, também acarretam em sérios problemas com o emprego indiscriminado, gerando graves riscos ao meio ambiente e ao homem (OLIVEIRA et al., 2009; DELECRODE et al., 2012).

Os inseticidas podem ser de efetiva utilidade na agricultura, se usados corretamente. O emprego impróprio pode resultar, não só no controle ineficiente de pragas, mas também na eliminação dos inimigos naturais que contribuem para 0 manejo dos insetos-praga. Dessa forma, devem-se criar estratégias para reduzir o uso de inseticidas, que resultará na diminuição dos custos de produção e dos danos ambientais promovidos por esses produtos (COLLI, 2011).

Uma alternativa ao uso de inseticidas é a utilização de cultivares resistentes aos insetos. No caso da soja, foi disponibilizado no mercado uma tecnologia com uso da transgenia, em que foi introduzido um gene que confere resistência às plantas de soja, essa tecnologia foi denominada de Intacta ${ }^{\circledR}$. As plantas transgênicas expressam a proteína Cry1Ac derivada da bactéria Bacillus thuringiensis (Bt), que confere á soja resistência aos principais insetos praga da ordem lepidóptera da cultura. Ao se alimentarem as lagartas iram ingerir a proteína Cry1Ac, que se ligar ao tubo digestivo das mesmas, promovendo o rompimento da membrana do intestino médio, o que ocasiona a morte (SOSA-GÓMEZI \& MIRANDA, 2012; MONSANTO, 2013).

Assim, com este trabalho objetivou-se verificar a viabilidade econômica no controle de lagartas na cultura da soja utilizando cultivares com e sem a tecnologia Intacta RR2 PRO ${ }^{\circledR}$ e inseticidas.

\section{MATERIAL E MÉTODOS}

O trabalho foi conduzido a campo, em uma área de cultivo comercial de soja, na safra 2014/2015, localizado no município de Três Palmeiras, situado no meio norte do Rio Grande do Sul, coordenadas geográficas 27ํ37’53.19"S ou 52०48'56.87"O.

AGRARIAN ACADEMY, Centro Científico Conhecer - Goiânia, v.4, n.7; p.382 2017 
O experimento foi implantado em um Latossolo Vermelho distrófico (EMBRAPA, 2006) em que adota-se o sistema de plantio direto a mais de 10 anos. Antes da semeadura foi realizada a análise química e física do solo, com base nessa análise foi realizada a adubação de base no momento da semeadura. $O$ delineamento experimental utilizado foi de parcelas subdivididas. As unidades experimentais utilizadas foram $20 \mathrm{~m}^{2}(4 \times 5 \mathrm{~m})$, com quatro repetições.

Os tratamentos foram alocados em fatorial $2 \times 4$. O primeiro fator, alocado nas parcelas, foi composto por duas cultivares de soja similares, Intacta NS 5959 IPRO $^{\circledR}$ e NA $5909 R^{\circledR}{ }^{\circledR}$. O segundo fator, alocado nas subparcelas, foi composto pelo tipo de controle utilizado, sendo os inseticidas: cipermetrina $\left(50 \mathrm{~g} \mathrm{ha}^{-1}\right)$, teflubenzurom $\left(15 \mathrm{~g} \mathrm{ha}^{-1}\right)$, cipermetrina + teflubenzurom $\left(50+15 \mathrm{~g} \mathrm{ha}^{-1}\right)$ e uma testemunha sem aplicação de inseticida (Tabela 1).

TABELA 1. Inseticidas utilizados para o controle de insetos na cultura da soja

\begin{tabular}{|c|c|c|c|c|}
\hline Mar & $\begin{array}{c}\text { Grupo } \\
\text { químico }\end{array}$ & Ingrediente ativo & Dose (g ia $h$ & $\begin{array}{l}\text { Número de } \\
\text { aplicações }\end{array}$ \\
\hline Cipermetrina $250^{\circledR} \mathrm{CE}$ & Piretroide & cipermetrina & 50 & 7,0 \\
\hline $\begin{array}{c}\text { Nomolt } 150^{\circledR} \\
\text { Cipermetrina } 250^{\circledR} \mathrm{CE} \\
+ \text { Nomolt } 150^{\circledR}\end{array}$ & $\begin{array}{c}\text { Benzoilureias. } \\
\text { Piretroide }+ \\
\text { Benzoilureias. }\end{array}$ & $\begin{array}{l}\text { teflubenzurom } \\
\text { cipermetrina }+ \\
\text { teflubenzurom }\end{array}$ & $\begin{array}{c}15 \\
50+15\end{array}$ & $\begin{array}{l}5,0 \\
5,0\end{array}$ \\
\hline
\end{tabular}

Nos tratamentos em que foram realizadas aplicações de inseticidas, as mesmas foram realizadas quando o nível populacional das lagartas atingiu o estágio de dano econômico (NDE) da lagarta-da-soja (CORRÊA-FERREIRA et al., 2010), sempre utilizando a cultivar sem a tecnologia Intacta ${ }^{\circledR}$, para realizar a avaliação populacional e calcular o NDE, pois observou-se que população de lagartas na cultivar com a tecnologia Intacta ${ }^{\circledR}$ foi inferior durante todo o ciclo da cultura. Foi realizada a quantificação e avaliação do NDE somente da lagarta-da-soja, pois foi a espécie que apresentou maior população.

Foram necessárias sete aplicações do inseticida cipermetrina para o controle das lagartas, cinco aplicações de teflubenzurom e cinco aplicações de cipermetrina + teflubenzurom. As primeiras aplicações foram realizadas quando a planta se encontrava no estádio V5 e as últimas no estádio R7.

As aplicações foram realizadas com um pulverizador manual, equipado com barra de aplicação com quatro bicos do tipo leque 110.02, distanciados a 0,5 metros, calibrado com regulador de vazão para pulverização de um volume de calda inseticida equivalente a $200 \mathrm{~L} \mathrm{ha}^{-1}$.

A soja foi semeada em sistema direto, sobre palhada da cultura do trigo, em espaçamento de 0,45 m entre linhas e população de 14,7 sementes por metro, resultando em aproximadamente 29,4 plantas por $\mathrm{m}^{2}$. As sementes foram tratadas antes da semeadura com fungicida e inseticida $\left(\right.$ Standak $\operatorname{Top}^{\circledR}$ ) de ação protetora (piraclotrobina), sistêmico (metil-tiofanato) e de contato e ingestão (fipronil). A adubação foi realizada na linha de semeadura, conforme análise de solo, utilizandose $350 \mathrm{~kg} \mathrm{ha}^{-1}$ do fertilizante com nitrogênio $(\mathrm{N})$, fósforo $(\mathrm{P})$ e potássio $(\mathrm{K})(02-25$ 25).

O controle das plantas daninhas foi realizado com o uso dos herbicidas glyphosate $\left(1440 \mathrm{~g} \mathrm{ha}^{-1}\right)$ e diclosulan $\left(25 \mathrm{~g} \mathrm{ha}^{-1}\right)$, aplicados quando a soja encontrava-se no estádio V5. O controle de doenças, especificamente a ferrugem-

AGRARIAN ACADEMY, Centro Científico Conhecer - Goiânia, v.4, n.7; p.383 2017 
asiática, foi realizado utilizando-se fungicidas formulados dos grupos das triazinas e estrobilurinas, que foram aplicados conforme recomendação para a cultura (OLIVEIRA \& ROSA, 2014), com três aplicações ao longo do ciclo da mesma.

No final do ciclo da cultura foram quantificados: os números de vagens por planta, número de grãos por vagem, número de grãos por plantas, massa de mil grãos e produtividade de grãos. Para avaliar as variáveis: número de vagens por planta, número de sementes por vagem foram coletadas, aleatoriamente, 10 plantas na área útil da parcela, desconsiderando as linhas laterais e $0,5 \mathrm{~m}$ no início e final da parcela. A colheita foi realizada com a coleta de todas as plantas contidas na área útil das parcelas, que, posteriormente, foram trilhadas.

Os grãos colhidos foram limpos e pesados, posteriormente, verificou-se a quantidade de umidade contida nos grãos, corrigindo a umidade para $13 \%$ e estimou-se a produtividade em $\mathrm{kg} \mathrm{ha}^{-1}$. A massa de mil grãos foi quantificada com a pesagem de oito repetições de 100 sementes por parcela.

Foram quantificados todos os custos de produção de todos os tratamentos, desde o preparo do solo para a implantação da cultura até a colheita, principalmente os custos diferentes entre as duas cultivares estudadas (Tabela 2). Posteriormente foram realizados os cálculos de comparação de custos entre a Soja NS5959 IPRO ${ }^{\circledR}$ com a tecnologia Intacta RR2 $\mathrm{PRO}^{\circledR}$ e a Soja NA $5909 \mathrm{RR}^{\circledR}$ sem a tecnologia e os custos com a aplicação dos inseticidas. Com os dados de produtividade e dos custos de produção foi possível calcular a viabilidade da implantação dessa tecnologia Intacta ${ }^{\circledR}$.

TABELA 2. Principais fatores com diferentes custos $\left(R \$ h a^{-1}\right)$, de produção de cultivares de soja com e sem a tecnologia Intacta $^{\circledR}$ (NS 5959 IPRO $^{\circledR}$ ) e (NA $5909 R R^{\circledR}$ ), respectivamente

\begin{tabular}{|c|c|c|c|c|c|c|c|c|}
\hline \multirow{2}{*}{ Descrição do Custo } & \multicolumn{2}{|c|}{ Sem inseticida } & \multicolumn{2}{|c|}{ Cipermetrina } & \multicolumn{2}{|c|}{ Teflubenzurom } & \multicolumn{2}{|c|}{$\begin{array}{l}\text { Cipermetrina } \\
\text { Teflubenzurom }\end{array}$} \\
\hline & $I^{1}$ & NI & I & NI & I & NI & I & NI \\
\hline Sementes & 397,5 & 116,6 & 397,5 & 116,6 & 397,5 & 116,6 & 397,5 & 116,6 \\
\hline Inseticida Contato & - & - & 7,0 & 49,0 & - & - & 7,0 & 49,0 \\
\hline Inseticida Sistêmico & - & - & - & - & 10 & 50,0 & 10,0 & 50,0 \\
\hline Aplicação de inseticida & - & - & 15,0 & 105,0 & 15,0 & 75,0 & 15,0 & 75,0 \\
\hline Outros (custos iguais) ${ }^{2}$ & 1220,5 & 1220,5 & 1220,5 & 1220,5 & 1220,5 & 1220,5 & 1220,5 & 1220,5 \\
\hline Total de custos & 1618,0 & 1337,1 & 1640,0 & 1491,1 & 1643,0 & 1462,1 & 1650 & 1511,1 \\
\hline
\end{tabular}

As receitas geradas com a lavoura da soja foi calculada com base na produtividade de grãos por hectare, considerando a venda da soja na época da colheita, que foi de $R \$ 62,00$ por saca de $60 \mathrm{~kg}$. Os dados coletados foram submetidos à Análise de Variância pelo Teste $F$, e quando observada diferença significativa, foi efetuado o teste de Tukey, ambos a $5 \%$ de probabilidade, utilizado 0 software Winstat ${ }^{\circledR}$ (MACHADO \& CONCEIÇÃO, 2007).

\section{RESULTADOS E DISCUSSÃO}

O número de vagens por planta apresentou diferença significativa entre as cultivares estudadas, exceto no tratamento que foi utilizado como testemunha, em que não observou-se diferença entre as cultivares (Tabela 3). Esse resultado é resultante das diferenças genéticas entre as cultivares utilizadas, a NA 5909 RR $^{\circledR}$ AGRARIAN ACADEMY, Centro Científico Conhecer - Goiânia, v.4, n.7; p.384 2017 
teve o desenvolvimento com um maior número de ramificações secundárias do que a Intacta NS 5959 IPRO $^{\circledR}$, que teve desenvolvimento de apenas uma haste principal sem ramificações para a inserção das vagens.

O número de vagens por planta é determinado pelo balanço entre a produção de flores por planta e a proporção destas que se desenvolvem até vagem. E o número de flores por planta, é determinado pelo número de flores por nó e pelo número de nós por planta. As gemas reprodutivas se desenvolvem a partir dos nós das plantas, assim a redução no número de ramificações reduz o número de nós potenciais e, consequentemente, o número de vagens na planta (AMORIM et al., 2011; SOUZA et al., 2013).

No fator envolvendo o controle das lagartas com inseticidas, dentro de cada cultivar, não teve diferença significativa no número de vagens (Tabela 3). Por se utilizar os mesmo tratos culturais em todo o desenvolvimento, como densidade de semeadura e fertilização. $O$ ataque das lagartas promoveu apenas a desfolha das plantas já desenvolvidas, sendo assim, o número de gemas reprodutivas foram similares em plantas atacadas ou não atacadas pelas lagartas.

TABELA 3. Número de vagens por planta e grãos por vagem da cultivar de soja Intacta NS 5959 IPRO $^{\circledR}\left(\right.$ Intacta $\left.^{\circledR}\right)$ e NA 5909 RR $^{\circledR}$ (não Intacta ${ }^{\circledR}$ ) em função do tipo de tecnologia e tratamentos com inseticidas

\begin{tabular}{lcccc}
\hline Cultivar & Testemunha & Cipermetrina & Teflubenzurom & $\begin{array}{l}\text { Cipermetrina + } \\
\text { Teflubenzurom }\end{array}$ \\
\hline & & Número de vagem por planta & \\
\hline Intacta & $48,1 \mathrm{Aa}^{1}$ & $44,35 \mathrm{Ba}$ & $46,45 \mathrm{Ba}$ & $46,45 \mathrm{Ba}$ \\
Não intacta & $53,15 \mathrm{Aa}$ & $52,05 \mathrm{Aa}$ & $54,15 \mathrm{Aa}$ & $54,80 \mathrm{Aa}$ \\
\hline \multicolumn{5}{c}{ Número de grãos por vagem } \\
\hline Intacta & $2,33 \mathrm{Aa}$ & $2,36 \mathrm{Aa}$ & $2,34 \mathrm{Aa}$ & $2,32 \mathrm{Aa}$ \\
Não intacta & $1,88 \mathrm{Ba}$ & $1,93 \mathrm{Ba}$ & $1,97 \mathrm{Ba}$ & $2,05 \mathrm{Ba}$
\end{tabular}

${ }^{1}$ Médias seguidas de mesma letra, maiúsculas na coluna e minúsculas na linha, dentro de cada variável, não diferem entre si pelo teste de Tukey a $5 \%$ de probabilidade.

O número de grãos por vagens apresentou diferença significativa entre as cultivares estudas dentro de cada fator de controle com inseticidas (Tabela 3). O número total de grãos está relacionado com o número total de vagens, com isso se reduzir o número total de vagens afetará diretamente o número de grãos por vagem (SOUZA et al., 2013). No entanto, com o mesmo número de vagens, se houver menor número de grãos por vagem há menor produção de grãos por planta.

Com a diminuição do número de vagens por planta observou-se um aumento no número de grãos por vagem na cultivar com a tecnologia Intacta ${ }^{\circledR}$, pois as plantas que apresentaram menor número de vagens puderam investir metabólitos em maior número de grãos por vagem. Mas não foi apenas esse fator que determinou o aumento do número de grãos por vagens na cultivar com a tecnologia Intacta ${ }^{\circledR}$, outro fator importante foram as injúrias proporcionadas pelas lagartas, na soja NA 5909 $R R^{\circledR}$, que não possui a resistência ao ataque das lagartas. Nesta cultivar muitos grãos foram danificados dentro das próprias vagens, inviabilizando os mesmos.

No fator tratamento com inseticidas, dentro de cada uma das cultivares, não observou-se diferença significativa (Tabela 3). Esse resultado deve-se ao fato dos tratamentos interferirem pouco nessa variável, visto que mesmo com o controle químico, na cultivar não resistente, alguns grãos foram atacados nas vagens, pois as aplicações foram realizadas quando a população de lagartas atingiu o NDE.

AGRARIAN ACADEMY, Centro Científico Conhecer - Goiânia, v.4, n.7; p. 3852017 
A variável número de grãos por planta não apresentou diferença significativa entre nenhum dos fatores, cultivar ou tratamentos com inseticida (Tabela 4). Essa variável permaneceu estável, mesmo obtendo-se diferença entre número de vagens por planta e número de grãos por vagem. Observou-se que nos tratamentos em que obteve-se menor número de vagens (cultivar resistente) foi obtido maior número de grãos por vagem, uma forma da planta compensar o baixo número de vagens.

Nas condições experimentais observou-se diferença entre as cultivares para a variável massa de mil grãos em função da tecnologia empregada para a resistência da soja às lagartas. A cultivar NS 5959 IPRO $^{\circledR}$ (Intacta $^{\circledR}$ ) possui o gene de resistência contra lagartas (MONSANTO, 2014), o que proporcionou menor desfolha da planta. Com maior índice de área foliar as plantas promovem maior atividade fotossintética, produzindo mais fotoassimilados, o que é fundamental para promover melhor enchimento dos grãos.

É importante destacar que, mesmo com a aplicação sequencial de inseticidas na cultivar que não possuía o gene de resistência, não foi possível obter similaridade na massa de mil grãos da cultivar resistente. Isso porque todas as aplicações foram realizadas quando já havia o $\mathrm{NDE}$, e a planta já havia perdido parte significativa da área foliar (CORRÊA-FERREIRA et al., 2010).

TABELA 4. Número de grãos por planta e massa de 1000 grãos da cultivar de soja Intacta NS5959 IPRO ${ }^{\circledR}\left(\right.$ Intacta $\left.^{\circledR}\right)$ e NA5909 RR ${ }^{\circledR}$ (não Intacta ${ }^{\circledR}$ ) em função do tipo de tecnologia e tratamentos com inseticidas

\begin{tabular}{lcccc}
\hline Cultivar & Testemunha & Cipermetrina & Teflubenzurom & $\begin{array}{c}\text { Cipermetrina + } \\
\text { Teflubenzurom }\end{array}$ \\
\hline \multicolumn{5}{c}{ Número de grãos por planta } \\
\hline Intacta & $111,85 \mathrm{Aa}$ & $104,85 \mathrm{Aa}$ & $108,75 \mathrm{Aa}$ & $108,15 \mathrm{Aa}$ \\
Não intacta & $100,40 \mathrm{Aa}$ & $100,85 \mathrm{Aa}$ & $107,10 \mathrm{Aa}$ & $111,15 \mathrm{Aa}$ \\
\hline \multicolumn{5}{c}{ Massa de 1000 grãos } \\
\hline Intacta & $168,15 \mathrm{Aa}^{1}$ & $169,85 \mathrm{Aa}$ & $169,825 \mathrm{Aa}$ & $170,6 \mathrm{Aa}$ \\
Não intacta & $146 \mathrm{Bb}$ & $155,6 \mathrm{Ba}$ & $151,825 \mathrm{Ba}$ & $156,2 \mathrm{Ba}$
\end{tabular}

${ }^{1}$ Médias seguidas de mesma letra, maiúsculas na coluna e minúsculas na linha, dentro de cada variável, não diferem entre si pelo teste de Tukey a $5 \%$ de probabilidade.

O peso médio dos grãos é uma característica determinada geneticamente, sendo essa influenciada por fatores ambientais, sendo assim, uma planta que promove maior taxa fotossintética poderá alocar maior quantidade de fotoassimilados nos grãos. Segundo SOUZA et al. (2013), a formação de vagens pode ser prejudicada se houver limitações da área fotossinteticamente ativa (área foliar) o que pode interferir, também, no enchimento dos grãos.

No fator envolvendo os diferentes inseticidas, dentro das cultivares, não foi observada diferença significativa da massa de 1000 grãos na soja resistente. $\mathrm{Na}$ cultivar NA $5909 \mathrm{RR}^{\circledR}$ (sem o gene de resistência) observou-se diferença significativa, em que a testemunha (sem aplicação de inseticidas) obteve menor massa de mil grãos quando comparada com os tratamentos que receberam algum inseticida, esses não apresentaram diferença. Esse efeito é atribuído ao maior ataque de lagarta nas plantas que não receberam aplicação de inseticida, tendo a área folhar reduzida de forma considerável (Tabela 4).

$\mathrm{Na}$ variável produtividade de grãos $\left(\mathrm{kg} \mathrm{ha}^{-1}\right)$ observou-se diferença significativa entre cultivares (Figura 1). Pode se perceber que independente do fator envolvendo a aplicação de inseticidas, todos os tratamentos obtiveram diferença AGRARIAN ACADEMY, Centro Científico Conhecer - Goiânia, v.4, n.7; p. 3862017 
significativa, com maior produtividade da cultivar de soja Intacta NS 5959 IPRO ${ }^{\circledR}$. Essa maior produtividade pode ser atribuída a tecnologia agregada a cultivar, que possuí um gene de resistência as lagartas (MONSANTO, 2014; CRIALESI-LEGORI et al., 2014) que protegeu as plantas dos danos causados pelos ataques desses insetos. Por outro lado, a cultivar NA $5909 \mathrm{RR}^{\circledR}$, mesmo com a utilização de inseticidas, obteve menor produtividade, pois os danos causados pelas lagartas nem sempre são possíveis de se reverter, considerando que até atingir o nível de dano as lagartas promovem uma desfolha considerável das plantas e o controle químico nem sempre é eficiente, se restar algumas lagartas podem promover elevados danos a cultura.

Comparando a produtividade de grãos, considerando o fator envolvendo a aplicação de inseticidas dentro de cada cultivar, pode se observar que a cultivar Intacta NS 5959 IPRO $^{\circledR}$ não apresentou diferença com ou sem a aplicação de inseticidas (Figura 1), comprovando a eficiência do gene de resistência no combate das lagartas. A cultivar de soja NA $5909 \mathrm{RR}^{\circledR}$, sem o gene de resistência, apresentou diferentes produtividades nas parcelas com e sem aplicação de inseticidas. Os tratamentos em que foram aplicados inseticidas apresentaram produtividade similar, sendo superiores quando comparada com a testemunha sem aplicação, obtendo-se produtividade superior de, em média, $350 \mathrm{~kg} \mathrm{ha}^{-1}$ de grãos (Figura 1). Os inseticidas apresentaram eficiência semelhante com relação à proteção das plantas, destacando-se que a frequência de aplicação do inseticida de contato (cipermetrina) foi maior, pois esse inseticida não apresenta residual e as populações de lagartas logo voltavam a atingir o NDE.

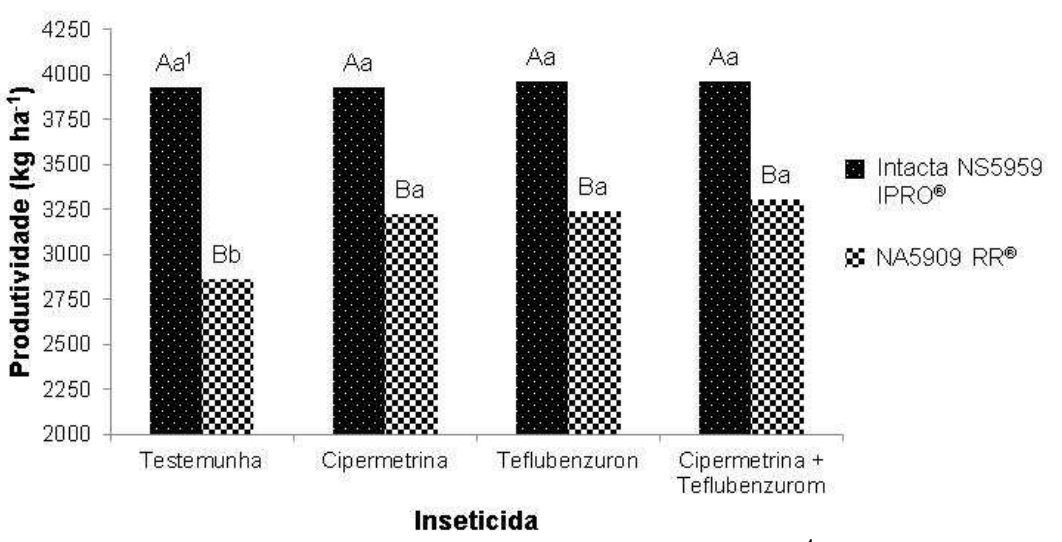

FIGURA 1. Produtividade da soja $\left(\mathrm{kg} \mathrm{ha}^{-1}\right)$ em função da cultivar, com e sem a tecnologia Intacta ${ }^{\circledR}$, e aplicação de inseticidas.

${ }^{1}$ Médias seguidas de mesma letra, maiúsculas entre cultivares e minúsculas entre inseticidas, não diferem entre si pelo teste de Tukey a 5\% de probabilidade.

$\mathrm{Na}$ variável custo de produção observou-se interação significativa entre os fatores estudados (Figura 2). Os custos foram diferentes entre as cultivares, e entre os inseticidas utilizados, pois cada cultivar e produto químico gera um custo diferente. Pode-se perceber que a cultivar com o gene de resistência tem um custo maior de produção em todos os tratamentos em comparação a soja NA $5909 R^{\circledR}{ }^{\circledR}$, esse maior custo é gerado exclusivamente pela aquisição das sementes, que tem valor mais elevado, pois é no momento da aquisição das sementes que são pagas 
as taxas tecnológicas para uso da tecnologia da resistência.

$\mathrm{Na}$ avaliação dos custos, com relação à aplicação de inseticida, dentro de cada cultivar, percebe-se diferença em ambas as cultivares (Figura 2). Observou-se diferença de custo entre todos os tratamentos com inseticidas, considerando que o menor custo foi obtido na testemunha, sem a aplicação de inseticidas. O menor custo dos tratamentos com aplicação de inseticida foi obtido com a aplicação do teflubenzurom, pois esse inseticida apresenta efeito sistêmico e foi realizado em menor número de aplicações, o custo intermediário foi obtido com a aplicação da cipermetrina, inseticida de contato em que houve a necessidade de maior número de aplicações. O maior custo foi obtido nos tratamentos com a aplicação de ambos os inseticidas em associação, que resultou em valores superiores em função do uso de ambas as moléculas nas mesmas doses utilizadas isoladamente (Figura 2).

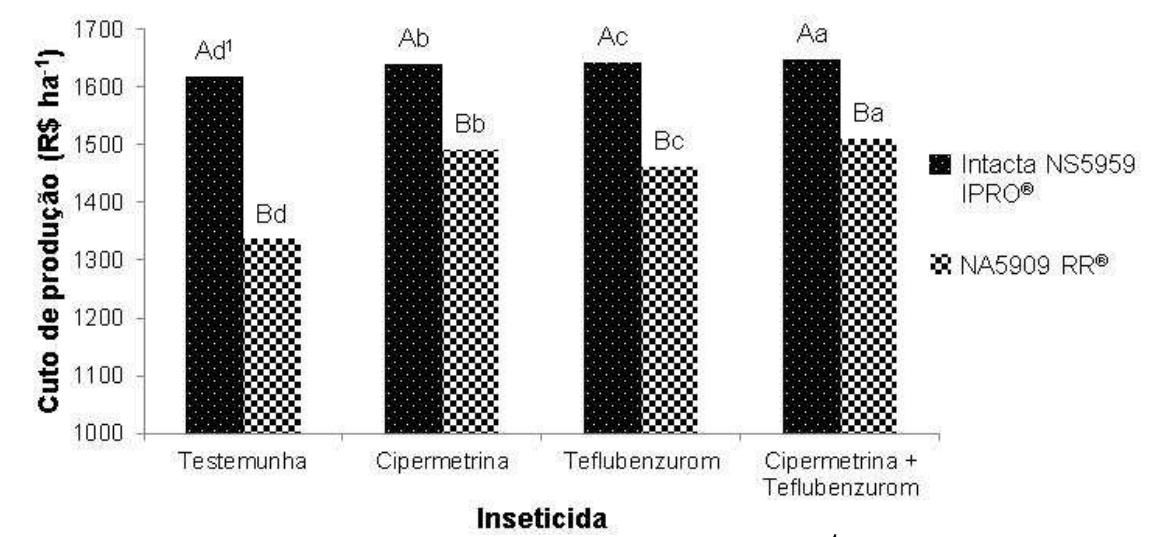

FIGURA 2. Custo de produção $\left(R \$ h^{-1}\right)$ em função da cultivar, com e sem a tecnologia Intacta ${ }^{\circledR}$, e aplicação de inseticidas.

${ }^{1}$ Médias seguidas de mesma letra, maiúsculas entre cultivares e minúsculas entre inseticidas, não diferem entre si pelo teste de Tukey a $5 \%$ de probabilidade.

Relacionando os custos a produtividade e considerando o valor de mercado da saca de soja na época da colheita (saca de $60 \mathrm{~kg}$ ao valor de $R \$ 62,00$ ), foi possível calcular a lucratividade para cada tratamento, considerando os fatores envolvidos. Nesse sentido, pode-se identificar que a soja cultivar Intacta NS 5959 IPRO ${ }^{\circledR}$ apresentou melhor retorno econômico (lucratividade) em comparação a NA $5909 \mathrm{RR}^{\circledR}$, mesmo com maior custo de produção obteve-se maior produtividade e consequentemente maior valor na venda (Figura 3).

Comparando os tratamentos com uso de inseticidas, em cada cultivar, podese observar que para a cultivar Intacta NS 5959 IPRO ${ }^{\circledR}$ obteve-se mesma lucratividade (Figura 3), desse modo não há necessidade da aplicação de inseticidas, pois a cultivar apresenta resistência efetiva às lagartas (SOSA-GÓMEZI \& MIRANDA, 2012), não justificando a aplicação de inseticidas, esses que podem causar elevado impacto ambiental.

O retorno econômico envolvendo a cultivar NA $5909 R^{\circledR}{ }^{\circledR}$ comporta-se de maneira distinta, pois nesse caso, os tratamentos que receberam a aplicação de inseticidas apresentaram maior lucratividade (Figura 3), diferindo do tratamento testemunha, que não recebeu a aplicação de inseticidas. Apesar dos tratamentos com inseticidas apresentarem custos diferentes à lucratividade, foi similar para todos (Figura 3). 


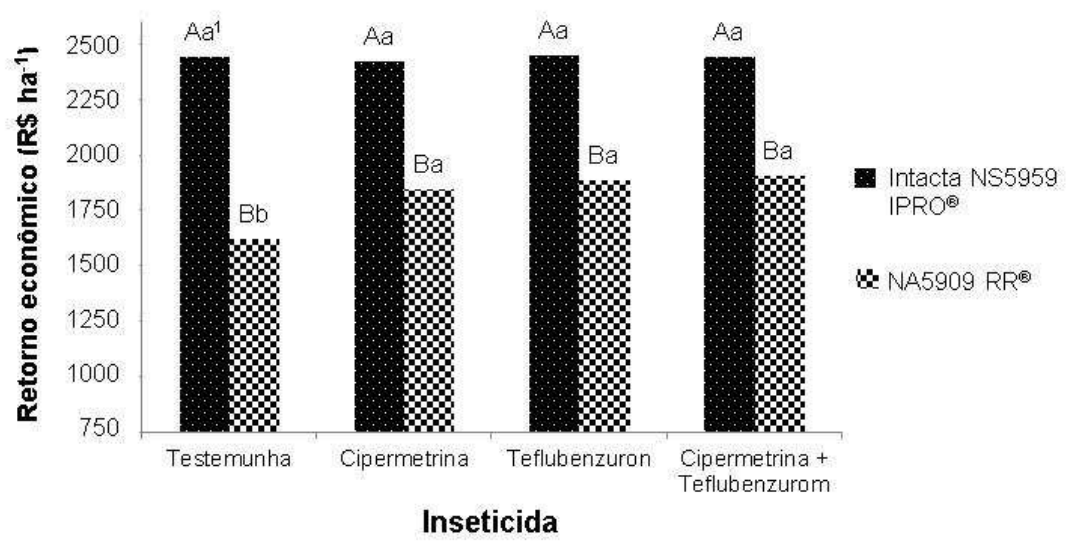

FIGURA 3. Retorno econômico $\left(R \$ h^{-1}\right)$ em função da cultivar, com e sem a tecnologia Intacta ${ }^{\circledR}$, e aplicação de inseticidas.

\footnotetext{
${ }^{1}$ Médias seguidas de mesma letra, maiúsculas entre cultivares e minúsculas
} entre inseticidas, não diferem entre si pelo teste de Tukey a $5 \%$ de probabilidade

\section{CONCLUSÃO}

A cultivar de soja Intacta NS 5959 IPRO ${ }^{\circledast}$ apresenta resistência à lagarta-dasoja (Anticarsia gemmatalis), obtendo-se elevadas produtividade sem a necessidade da aplicação de inseticidas.

A produtividade obtida pela cultivar com a tecnologia $\operatorname{Intacta}^{\circledR}$ foi superior, independentemente da aplicação de inseticidas. A cultivar sem a tecnologia Intacta ${ }^{\circledR}$ necessita de repetidas aplicações de inseticidas para elevar sua produtividade.

Apesar do custo de produção da soja com a tecnologia Intacta ${ }^{\circledR}$ ser mais elevado, essa cultivar promove maior retorno econômico.

\section{REFERÊNCIAS}

AMORIM, F.A.; HAMAWAKI, O.T.; SOUSA, L.B.; LANA, R.M.Q.; HAMAWAKI, C.D.L. Época de semeadura no Potencial produtivo de Soja em Uberlândia-MG. Semina: Ciências Agrárias, v.32, n.1, p.1793-1802, 2011. Disponível em: $<$ www.uel.br/revistas/uel/index.php/semagrarias/article/download/5398/9138>. DOI: DOI: 10.5433/1679-0359.2011v32Suplp1793.

COLLI, W. Organismos transgênicos no Brasil: regular ou desregular?. Revista USP, n.89, p.148-173, 2011. Disponível em: $<$ http://rusp.scielo.br/scielo.php?script=sci_arttext\&pid=S010399892011000200011\&lng=pt\&nrm=iso >. ISSN: 0103-9989.

CONAB - Companhia Nacional de Abastecimento. Acompanhamento da safra brasileira de grãos - 2016/17. Acompanhamento da safra brasileira de grãos, v.4, n.9, $2017 . \quad$ Disponível em: <http://www.conab.gov.br/OlalaCMS/uploads/arquivos/17_06_08_09_02_48_boletim _graos_junho_2017.pdf>.

CORRÊA-FERREIRA, B;S; AleXandre, T;M; Pellizzaro. E;C. Práticas de 
manejo de pragas utilizadas na soja e seu impacto sobre a cultura da soja. Circular técnico 78, Embrapa Soja: Londrina, PR, 2010. Disponível em: < http://www.cnpso.embrapa.br/download/CT78VE.pdf>. ISSN: 2176-2864.

CRIALESI-LEGORI, P.C.B.; DAVOLOS, C.C.; LEMES, A.R.N.; MARUCCI, S.C.; LEMOS, M.V.F.; FERNANDES O.A.; DESIDÉRIO, J.A. Interação de proteínas Cry1 e Vip3A de Bacillus thuringiensis para controle de lepidópteros-praga. Pesquisa Agropecuária Brasileira. v.49, n.2, p.79-87, 2014 Disponível em: < http://www.scielo.br/pdf/pab/v49n2/0100-204X-pab-49-02-00079.pdf >. DOI: 10.1590/S0100-204X2014000200001

CUNHA, D.S.; VIANA, J.S.; SILVA, W.M.; SILVA, J.M. Soja para consumo humano: breve abordagem. Agrarian Academy, v.2, n.3; p.101-113, 2015. Disponível em: http://www.conhecer.org.br/Agrarian\%20Academy/2015a/soja\%20para\%20consumo. pdf. DOI: 10.18677/Agrarian_Academy_010.

DELECRODE, C.R.; FREITAS, T.D.; FRIZZO, A.C.F.; CARDOSO, A.C.V. A prevalência do zumbido em trabalhadores expostos à ruído e organofosforados. International Archives of Otorhinolaryngology, v.16, n.3, p. 328-334, 2012. Disponível em: <http://www.scielo.br/scielo.php?script=sci_arttext\&pid=S1809$48642012000300005 \&$ Ing=en\&nrm=iso $>$. DOI: $10.7162 / S 1809-97772012000300005$.

EMBRAPA. Centro Nacional de Pesquisa de Solos. Sistema brasileiro de classificação de Solos. 2. ed. Rio de Janeiro: Embrapa Solos, 2006. 306 p. ISBN 85-85864-19-2.

FREITAS, R.E.; MENDONÇA, M.A.A. Expansão Agrícola no Brasil e a Participação da Soja: 20 anos. Revista de Economia e Sociologia Rural, v.54, n.03, p.497-516, 2016. Disponível em: http://www.scielo.br/pdf/resr/v54n3/1806-9479-resr-54-0300497.pdf. DOI: 10.1590/1234-56781806-94790540306.

HOFFMANN-CAMPO, C.B.; MOSCARDI, F.; CORREAA-FERREIRA, B.S.; OLIVEIRA, L.J.; SOSA-GÓMEZ, D.R.; PANIZZI, A.R.; CORSO, I.C.; GAZZONI, D.L.; OLIVEIRA, E.B. Pragas da soja no Brasil e seu manejo integrado. Londrina: Embrapa Soja, $2000.70 p$. Disponível em: <https://www.agencia.cnptia.embrapa.br/Repositorio/circtec30_000g46xpyyv02wx5o k0iuqaqkbbpq943.pdf>. ISSN 1516-7860.

LOURENÇÃO, A.L.; RECO, P.C.; BRAGA, N.R.; VALLE, G.E. PINHEIRO, J.B. Produtividade de genótipos de soja sob infestação da lagarta-da-soja e de percevejos. Neotropical Entomology, v.39, n.2, p. 275-281, 2010. Disponível em: <http://www.scielo.br/pdf/ne/v39n2/v39n2a20.pdf>. $\quad$ DOI: $\quad 10.1590 / S 1519-$ 566X2010000200020.

MACHADO, A. A.; CONCEIÇÃO, A. R. Winstat - Sistema de Análise Estatística para Windows. Universidade Federal de Pelotas, RS. 2007. CD-ROM.

MAUAD, M.; SILVA, T.L.B.; ALMEIDA NETO, A.I.; ABREU, V.G. Influência da densidade de semeadura sobre características agronômicas na cultura da soja. Agrarian, v.3, n.9, p.175-181, 2010. Disponível em: 
<http://ojs.ufgd.edu.br/index.php/agrarian/article/view/75/649>. ISSN: 1984-2538.

MONSANTO DO BRASIL. Monsanto apresenta Intacta RR2 PRO, nova tecnologia para soja desenvolvida com exclusividade para o Brasil, no Showtec 2014. Disponível em: <http://www.monsanto.com/global/br/noticias/pages/monsanto-apresenta-intacta-rr2pro-nova-tecnologia-soja-desenvolvida-exclusividade-brasil-showtec-2014.aspx>. Acessado em: 02 de julho de 2017.

MORALES, L.; SILVA, M.T.B. Desafios do MIP-soja na região sul do Brasil e o plantio direto. In: Congresso Brasileiro de Soja, 4., 2006, Londrina. Anais... Londrina: Embrapa Soja, 2006. p. 134-139.

OLIVEIRA, A.C.B.; ROSA, A.P.S.A. Indicações técnicas para a cultura da soja no Rio Grande do Sul e em Santa Catarina, safras 2014/2015 e 2015/2016. Embrapa Clima Temperado: Pelotas/RS, 2014. 124p. Disponível em: < https://www.infoteca.cnptia.embrapa.br/infoteca/bitstream/doc/1011192/1/Indicacoes TecnicasEmbrapa003.pdf>. ISSN: 1516-8840.

OLIVEIRAI, T.A.; SANTOS, J.B.; CAMELO, G.N.; BOTELHO, R.G.; LÁZARI, T.M. Efeito da interação do nicosulfuron e chlorpyrifos sobre o banco de sementes e os atributos microbianos do solo. Revista Brasileira de Ciência do Solo, v.33, n. 3, p.563-570, 2009. Disponível em: $<$ http://www.scielo.br/scielo.php?script=sci_arttext\&pid=S0100-

$06832009000300009 \&$ Ing=en\&nrm=iso $>$. DOI: 10.1590/S0100-06832009000300009.

SOSA-GÓMEZI, D.R.; MIRANDA, J.E. Fitness cost of resistance to Bacillus thuringiensis in velvetbean caterpillar Anticarsia gemmatalis Hübner (Lepidoptera, Noctuidae). Revista Brasileira de Entomologia, v.56, n.3, p.359-362, 2012. Disponível em: < http://www.scielo.br/pdf/rbent/v56n3/aop5112.pdf >. DOI: 10.1590/S0085-56262012005000050.

SOUZA, C.A.; FIGUEIREDO, B.P.; COELHO, C.M.M.; CASA, R.T.; SANGOI, L. Arquitetura de plantas e produtividade da soja decorrente do uso de redutores de crescimento. Bioscience Journal, v.29, n.3, p.634-643, 2013. Disponível em: < http://www.seer.ufu.br/index.php/biosciencejournal/article/view/14181>. ISSN: 19813163. 